\title{
Poles Apart?: The Social Construction of Responsibility for Climate Change in Australia and Norway
}

\author{
ROBYN ECKERSLEY ${ }^{1}$
}

\begin{abstract}
This article provides a comparative discourse analysis of the climate responsibility narratives of Australian and Norwegian political leaders during the period 2007-2012. The analysis focuses on how political leaders imagine their country's identity and role in the world and how they connect (or disconnect) these identities, roles and interests with responsibility for climate change, and with their respective energy policies. The analysis shows that the striking differences in mitigation ambition and responsibility discourses between Australia and Norway are clearly related, but cannot be reduced, to differences in their relative dependence on fossil fuel. Rather, differences in national identity and international role conception provide a far more illuminating account than a simple interest-based explanation. However, Australia and Norway are not quite so "poles apart" on their energy policies, and I briefly explore the implications of climate policy hypocrisy.
\end{abstract}

Since the signing of the United Nations Framework Convention on Climate Change (UNFCCC) in 1992, developed countries have been under strong pressure to play a leadership role in mitigation by virtue of their greater historical and per capita emissions, and greater wealth and capacity, than developing countries. This pressure has persisted despite ongoing contestation over the Convention's burden sharing principles of common but differentiated responsibilities and capabilities, and the rapid growth of emissions in major developing countries. However, only some developed countries have embraced these leadership obligations by committing to emissions reductions that are consistent with scientific recommendations. Understanding this variation is one of the great puzzles of comparative climate policy that can shed light on the possibilities and limits of political transformation towards a decarbonised world, including whether Australia may be able to play a more active role in this process.

\footnotetext{
${ }^{1}$ I wish to thank Dina Hestad for her excellent research assistance in collecting primary and secondary texts for the Norwegian case study, and for translating many Norwegian texts into English. I also wish to thank Mendo Kundevski for his excellent research assistance in collecting primary and secondary texts for the Australian case study.
} 
Those who seek parsimony in social scientific explanation typically reach for a simple interest-based explanation to account for differences in national mitigation ambition, based on relative dependence on fossil fuels. On this account, Saudi Arabia's energy and climate policies are emblematic of the policy repertoire expected of a "carboniferous state". Yet this account treats national interests as exogenous to social interaction, standing prior to, behind or "underneath" climate policy, and serving as the fundamental drivers of the normative order. It therefore cannot account for the differentiated responsibilities conferred on developed and developing states under the UNFCCC. Nor can it shed light on the social meaning of the fossil fuels that lie under the ground or sea-bed, and the reasons why and how they should be brought to the surface (or not). And, most importantly, it cannot explain climate leadership ambition other than by pointing to the relative presence or absence of obstacles to leadership. While heavy fossil fuel dependence can certainly raise the bar for aspiring climate leaders, an interest-based explanation cannot explain the source of the aspiration for leadership, and why and how some governments wish to lead while others choose to follow or obstruct.

This article seeks to highlight the limitations of an interest-based explanation of climate policy by comparing Australian discourses of responsibility for climate change with those of Norway, another developed country with which it has cooperated diplomatically. While discourse analysis is limited to addressing how policy is legitimated rather than why it is enacted, it can nonetheless highlight the various ways in which national interests are unavoidably tethered to, and legitimated by, particular identities, social roles and norms. As Lene Hansen explains, the relationship between identity and policy is performative and constitutive rather than causal: "Policies are particular directions for action, but they are also ontologically linked with particular identities, which provide the reason why policies should be enacted". ${ }^{2}$ Norms and policies do not serve as an ethical alternative to, restraint upon, or mask for underlying interests. Rather, they constitute the meaning of legitimate interests. ${ }^{3}$

Identities, and the social roles and norms to which they give rise, are no more or less stable than the discourses that produce them. ${ }^{4}$ By discourses I mean provisional, but

\footnotetext{
${ }^{2}$ Lene Hansen, Security as Practice: Discourse Analysis and the Bosnian War (Abingdon, 2006), pp. 2 and 21.

${ }^{3}$ Audie Klotz, "Norms Reconstituting Interests: Global Racial Equality and U.S. Sanctions Against South Africa”, International Organization, Vol. 49, 3 (Summer, 1995), pp. 451-478, p. 460.

${ }^{4}$ The key difference between social roles and social identities is that the latter include qualities that do not necessarily entail the answerability to others that comes with the discharge of socially ascribed roles. This is an important distinction since it explains the misfit between internationally ascribed roles and responsibilities (such as those conferred on developed countries by the international climate regime) and self-ascribed responsibilities and roles derived from national identities.
} 
relatively stable, recurring patterns of signification that construct social realities by placing certain forms of knowledge, categories, norms and supporting arguments in a particular relationship in a sign system in ways that privilege the chosen assemblage over others.

Discourses are "productive" in the sense that they seek to both enable or disable, or legitimise or marginalise particular knowledge/power relations. They can be attributed to particular professions, epistemic communities, "discourse coalitions", political parties and individuals. Here I focus on the climate discourses of leaders and relevant ministers and shadow ministers in the mainstream political parties in government and opposition, since they provide the primary cues for political reporting by the media. These political discourses are typically tightly scripted, with significant repetition (to stay "on message") and are performed in highly staged settings, all of which make the task of identifying recurring patterns of signification relatively easy for the discourse analyst. The discourses are characterised on the basis of extensive reading of primary texts such as parliamentary speeches, press club speeches, press releases, media interviews, You Tube videos, political memoirs, and official government websites. My key focus has been on how political leaders construct the problem of climate change, how they narrate national responsibility and interests in response to the international climate regime (including their key categories, arguments, sources of authority and persuasive devices), and how they address the relationship between their climate and energy policies. I also highlight how political leaders imagine their country's identity and role in the world and how they connect (or disconnect) these identities, roles and interests with responsibility for climate change.

To set the context for the comparative discourse analysis I begin with a brief outline of climate diplomacy and policy in Norway and Australia, focussing in particular on their striking differences in mitigation ambition since 2007. The analysis that follows reveals some marked differences in the climate responsibility narratives of Australian and Norwegian political leaders, along with different responses to managing the tensions between energy and climate policy. These differences are clearly related to, but cannot be reduced to, relative fossil fuel dependence, since they are refracted through different political ideologies, national identities and international role conceptions.

\section{Australian and Norwegian Climate Policy: Converging and Diverging}

Australia and Norway share a number of significant commonalities that provide a fruitful basis for comparing climate discourses. First, both Norway and Australia are major fossil 
fuel exporters, with a powerful resource sector, and neither has shown any signs of forsaking the short-term gains to be had from such exports for so long as there remain significant reserves of coal, oil and/or gas to exploit within their onshore or offshore territories. ${ }^{5}$ However, their domestic energy profiles differ substantially. Hydro-electricity provides around $95-99 \%$ of Norway's domestic generation while over $75 \%$ of Australia's electricity generation is based on coal. ${ }^{6}$

Second, Australia and Norway emerged from Kyoto in 1997 as two of the only three countries in Annex B of the Protocol to negotiate a net increase in their emissions in the first commitment period of 2008-2012, with Australia negotiating an eight per cent increase and Norway a one per cent increase in emissions from a 1990 base. Norway and, after some delay, Australia have also both agreed to commit to a second commitment period under the Kyoto Protocol, and they are both strong supporters of its flexibility mechanisms.

Third, both countries have cooperated as members of the loose negotiating coalition known as the Umbrella group, which formed after the adoption of the Kyoto Protocol, and is made up of most of the developed countries outside the European Union that share different kinds of fossil fuel dependence. ${ }^{7}$

Finally, both countries embarked upon a significant revamping of their climate policies in 2007 under social democrat (Norwegian Labour/Australian Labor) governments. However, it is at this point that the interesting differences emerge. In 2007, Prime Minister Jens Stoltenberg (leading a minority Labour government with the support of the Socialist Left Party and the agrarian Centre Party) released a Climate White Paper that launched Norway's quest to become a world leader in climate change. ${ }^{8}$ This included a voluntary upgrade of its original Kyoto target by ten percent, corresponding to a new target of minus nine per cent below the 1990 levels by 2008-2012. The Paper also committed Norway to a unilateral reduction of emissions of 30 per cent by 2020 (from 1990 levels), rising to minus 40 percent if there is agreement among the major emitters to reduce emissions consistent with a two

\footnotetext{
${ }^{5}$ See, for example, Norwegian Ministry of Petroleum and Energy, An Industry for the Future: Norway's Petroleum Activities, Meld. St. 28 (2010-2011) Report to the Storting (White Paper); and Australian Government, Energy White Paper 2012: Australia's Energy Transformation (Canberra, 2012).

${ }^{6}$ IEA, Energy Policies of IEA Countries - Norway 2011 Review (Paris, 2011); Department of Resources, Energy and Tourism, “Australia's Coal Industry". Available at: http://www.ret.gov.au/resources/mining/australian_mineral_commodities/coal/pages/australia_coal_industry.asp $\underline{x}$.

${ }^{7}$ The other members of the Umbrella Group are the US, Canada, Japan, New Zealand, the Russian Federation and Ukraine.

${ }^{8}$ Norwegian Ministry of the Environment, Norwegian Climate Policy: Summary in English: Report No. 34 (2006-2007) to the Storting. Available at http://www.regjeringen.no/en/dep/md/press-centre/Pressreleases/2007/new-measures-to-reach-norways-ambitious-.html?id=473402
} 
degrees scenario, subject to continuation of the flexibility mechanisms. The Paper also declared that Norway would aim for complete carbon neutrality by 2050 (or by 2030 if an ambitious global agreement is reached). ${ }^{9}$

These ambitious goals were were backed by six of the seven parties in the Storting (the Norwegian parliament) in a political settlement reached in January 2008. ${ }^{10}$ Norway had already introduced a carbon tax as earlier as 1992, followed by an emissions trading scheme in 2005, which was linked to the EU's Emissions Trading Scheme in 2008. A second White Paper, released in April 2012, outlined a range of further measures to achieve the ambitious targets and imposed a requirement that two-thirds of Norway's emission cuts must be made domestically. ${ }^{11}$ However, critics have questioned the effectiveness of the measures and Norway's Petroleum White Paper (2010-2011) makes it clear that petroleum will remain, as the title of the paper makes clear, An Industry for the Future, and that Norway will make every effort to exploit all known reserves of fossil fuels in its territory while continuing exploration for new fields. ${ }^{12}$

The election of the Rudd Labor government in November 2007 ushered in a significant shift in direction in climate policy and diplomacy in Australia with the ratification of the Kyoto Protocol as the first act of government. The new Rudd government declared that it would reduce emissions by $60 \%$ by 2050 from 2000 levels and at the Copenhagen meeting in 2009 it committed to a unilateral 2020 target of a five percent cut in emissions from a 2000 (rather than 1990) baseline, rising to between minus 15-25 percent depending on the level ambition of an international agreement involving all major emitters. ${ }^{13}$ Following Labor's sacking of Rudd as leader and the 2010 election (covered in detail in Kate Crowley's contribution to this special issue), the interim carbon tax enacted by the new minority Gillard Labor government rested on the same modest 2020 target and a more ambitious 2050 target

\footnotetext{
${ }^{9}$ Norwegian Ministry of the Environment, Norway's Fifth National Communication Under the United Nations Framework Convention on Climate Change: Status Report as of December 2009. Available at http://unfccc.int/resource/docs/natc/nor_nc5.pdf

${ }^{10}$ Riksrevisjonen, The Office of the Auditor General's Investigation into Target Achievement in Climate Policy, Document 3:5 (2009-2010), p. 7. The exception was the right wing Progress Party.

${ }^{11}$ For a summary of the White Paper, see http://www.regjeringen.no/en/dep/smk/press-center/Pressreleases/2012/ambitious-norwegian-white-paper-on-clima.html?id=679419 These new measures included doubling the $\mathrm{CO} 2$ tax on the oil industry to NOK 420 per ton of $\mathrm{CO} 2$, a new climate and energy fund, discouraging car transport and more incentives for public transport, tree planting, a complete phase out of oilbased heating in buildings, a new energy research centre and the construction of at least one full-scale demonstration facility for carbon capture and storage by 2020.

${ }^{12}$ Norwegian Ministry of Petroleum and Energy, An Industry for the Future.

${ }^{13}$ Department of Climate Change and Energy Efficiency, Fact Sheet: Australia's Emission Reduction Targets. Available at http://www.climatechange.gov.au/en/government/reduce/national-targets/factsheet.aspx
} 
of minus $80 \% .{ }^{14}$ However, the Gillard government's Energy White Paper of 2012, which outlines a long term "clean energy transformation" by 2050, envisages Australia playing a continuing role as a major energy supplier to Asia and other "growth markets", with continuing strong growth in coal and gas production (including onshore and offshore LNG projects and coal seam gas). ${ }^{15}$

Norway's mitigation targets are radically more ambitious than Australia's, and are among the highest in the world (alongside Germany, the United Kingdom and Denmark), while Australia's targets hover in the lower band of developed countries. This stark difference cannot be explained away simply on the basis of Australia's heavier domestic dependence on fossil fuels compared to Norway's reliance on hydro-power, since Norway faces very high marginal abatement costs. Norway's emissions are rising from the petroleum, manufacturing and transport sectors and it is under strong political pressure to find new sources of domestic electricity generation as an alternative to drawing on the Nordic power market during low-rainfall seasons. ${ }^{16}$ Norway can therefore only achieve its ambitious 2020 target (two thirds of which must be domestic reductions) by reducing its emissions from oil and gas production, manufacturing and transport while also ensuring that all new forms of electricity generation are carbon neutral. ${ }^{17}$ As we shall see, differences in national identity and international role conception provide a far more illuminating account of why Norway and Australia, despite their shared interest in fossil fuel exploitation, are "poles apart" in their climate ambition. However, they are not quite so "poles apart" on their energy policies, and I briefly explore the discursive implication of climate policy hypocrisy in the conclusion.

\section{Norway: Moral and Technological Heroism and Atonement}

With the exception of the Progress Party, climate denialism is largely absent from national climate discourses in Norway, and climate change is generally acknowledged as a serious problem that requires a concerted national response without waiting to see how other countries will act. Against this background, the main bone of political contention has been

\footnotetext{
${ }^{14}$ See also Giorel Curran, "Modernising Climate Policy in Australia: Climate narratives and the undoing of a Prime Minister", Environment and Planning C, Vol. 29, 6 (2011), pp. 1004-17.

${ }^{15}$ Australian Government, Energy White Paper 2012.

${ }^{16}$ While Norway has further hydro-power capacity, there is strong environmental opposition against further large hydro-schemes, and new gas-fired power plants will only be approved if they include CCS.

${ }^{17}$ IEA, Energy Policies of IEA Countries: Norway - 2011 Review, p. 9.
} 
how to characterize and discharge Norway's climate leadership responsibilities in ways that reduce the tension with Norway's energy policy.

Prior to the release of the White Paper in 2007, the main line of discursive conflict had already been clearly drawn around the question of the degree to which Norway should discharge its responsibilities through domestic versus international action - characterized as the "national action" discourse versus "thinking globally" discourse. ${ }^{18}$ The former maintains that Norway's moral responsibility to protect the climate must be discharged by leading by example, which requires taking domestic action to reduce emissions through unilateral domestic targets and measures rather than out-sourcing responsibility by investing in international mitigation measures. The most consistent proponent of national action has been Kjell Magne Bondevik, a Lutheran Minister and Christian Democratic Party leader who served as Prime Minister from 1997-2000 and from 2001-2005. For example, in a speech launching the Government's Environmental Policy in 1999 he declared,

In order to make room for the necessary improvements in the welfare of the poor countries, we in the rich countries must be prepared to change our patterns of consumption. The natural foundation of our planet cannot tolerate a continuation of consumption in the rich world at the same rate, at the same time that the developing countries are raising their standard of living. ${ }^{19}$

In contrast, the thinking globally discourse frames climate change as an international problem where national action is less significant and international action is more appropriate and effective given the international nature of the problem. This discourse draws on macroeconomic reasoning and defends the virtues of carbon markets, such as trading and offsetting, because they provide the most internationally cost-effective emissions reductions.

In 1990 the Labour government led by Gro Harlem Brundtland had invoked the national action discourse to reject a proposal to build an on-shore, gas-fired power station (drawing on the off-shore Heidrun field) because it would compromise Norway's 1989

\footnotetext{
18 Eivind Hovden and Gard Lindseth, "Discourses in Norwegian Climate Policy: National Action or Thinking Globally?", Political Studies Vol. 52, 1 (2004), pp. 63-81; Eivind Hovden and Gard Lindseth, "Norwegian Climate Policy 1989-2002”, in Realizing Rio in Norway: Evaluative Studies of Sustainable Development, eds. William M. Lafferty, Morten Nordskag, and Hilde Aakre, p. 141 (Oslo, 2002)

${ }^{19}$ Prime Minister Kjell Magne Bondevik, "The Government's environmental policy and the environmental state of the nation", 29 October 1999. Available at: http://www.regjeringen.no/nb/dokumentarkiv/RegjeringenBondevik-I/smk/Taler-og-artikler-arkivert-individuelt/1999/the-governments-environmental-policyand.html?id=571325
} 
stabilization target. ${ }^{20}$ When the gas-power debate re-emerged in the late 1990s, along with the prospect of carbon capture and storage (CCS), the Bondevik government likewise rejected gas power with CCS, insisting that Norway should discharge its responsibilities as a rich country by reducing emissions rather than capturing and storing them. Stoltenberg had initially embraced the national action discourse while serving as state secretary for the environment during the Heidrun debate, but during the course of the 1990s he became a strong proponent of the thinking globally discourse, and a defender of gas-fired power stations and CCS. Bondevik lost the parliamentary vote on the issue, enabling Stoltenberg to lead his first Labour government from 2000 to 2001 . He then led the Labour party to victory in 2005 and again in 2009.

The key discursive challenge for the Stoltenberg government after the release of the Climate White Paper in 2007 has been to minimize the tensions between Norway's role as a climate leader and its other role-conception as a high-tech, offshore petroleum and gas producer. His resolution of this "paradox" is to blend the thinking globally discourse with a narrative of national ambition, international generosity and technological heroism, knitted into an over-arching framework of (technologically driven) ecological modernization. ${ }^{21}$ The discourse accepts that developed countries have a leadership responsibility, particularly in setting an example through ambitious targets and in international financing and investment in low-carbon development, while developing countries have a responsibility to slow their emissions growth. Stoltenberg's New Year's address in 2007, broadcast in the wake of the new White Paper, provides the most emblematic "resolution" of the tensions:

Large parts of the country have had the warmest autumn and early winter for over a century. We see signs of this daily: our skis are standing unused, children aren't making snowmen, researchers warn that the polar bear is endangered...

...In Norway today it is not yellow canary birds that warn us, but yellow spring flowers blooming where there should be a blanket of snow...

\footnotetext{
${ }^{20}$ Hovden and Lindset, "Discourses in Norwegian Climate Policy", p. 67-68.

${ }^{21}$ Stoltenberg wrestles with these tensions in Kjetil B Alstadheim, Klima Paradokset [The Climate Paradox]: Jens Stoltenberg om vår tids største utfordring (Oslo, Aschehoug, 2010), a book based on a long interview with the journalist Kjetil Alstadheim.
} 
We must take our share of responsibility. Greenhouse gas emission must be reduced. Norway has taken on a pioneering role by deciding that the gas power plant at Mongstad will be required to have full-scale CO2 capture and storage (CCS). We are going to make this a reality.

When President Kennedy said that the Americans would land on the moon within 10 years they hadn't been in space yet. They got to the moon within 10 years. They set themselves a goal. And they reached it.

It is our vision that within seven years we will have put in place capture and storage technology. This will be an important breakthrough in the efforts to reduce greenhouse gas emissions in Norway, and once we succeed, I am convinced that the rest of the world will follow our example.

This is a major project for our country. It is our moon landing."22

This particular text taps into local, folksy wisdom and the Norwegian love of Nature, which demonstrate a palpable and lived, rather than abstract, experience of climate change. At the same time, the text effortlessly slides from the local to the national, and from the role of a moral to technological pioneer. Since CCS is not yet commercially viable, Stoltenberg calls on Norwegians to make a heroic leap of technological faith to make it happen. The development of CCS thereby serves as the ultimate enactment of Norway's national responsibility, complemented by the international trading and offsetting, and considerable international investment in protecting tropical forests.

Whereas the "old fashioned" national action discourse regards the Norwegian oil and gas industry as a problem that stands in the way of Norway fulfilling its leadership role, Stoltenberg's modernising narrative confers on the industry an honorable role. Given Norway's strict domestic environmental regulations, Norwegian oil and gas are more environmentally friendly than elsewhere. The export of gas-based power is also honorable

\footnotetext{
${ }^{22}$ Statsministerens Konto, Prime Minister Jens Stoltenberg's New Year's Address, 1 January 2007 http://www.regjeringen.no/nb/dep/smk/aktuelt/taler_og_artikler/statsministeren/statsminister_jens_stoltenberg/2 $007-4 /$ statsministerens-nyttarstale-2007/new-years-address.html?id=445669
} 
because, when sold into the Nordic region or the European grid, it would replace more emissions-intensive, coal-fired electricity in other countries. ${ }^{23}$

For the Labour government, the Norwegian petroleum industry helped to create the Norwegian welfare state, and it remains essential to the Labour vision of Norwegian nationbuilding and prosperity. Many of Norway's offshore petroleum fields have been given names from Norse mythology, but now that the "strongest names" are already in use the Norwegian Ministry of Petroleum and Energy is looking for new names that "reflect the industry's importance, both for specific regions and for the nation as a whole". ${ }^{24}$

Stoltenberg's is not a particularly tidy discourse since it depends upon a series of strained connections that have not managed to convince the Norwegian environment movement. It also requires much more knowledge brokerage than the national action discourse since it rests on a set of highly specialized, professional discourses (environmental economics, international carbon markets and accounting systems, and new technologies). In contrast, the national action discourse relies on a much more direct or unmediated understanding of responsible action, which requires simply refraining from investing in further fossil fuel projects and reducing the consumption of fossil fuels. ${ }^{25}$ This is more important to the Christian Democratic Party and Liberal Party than the more pragmatic Labour Party.

Despite these differences, most of the mainstream discourses display a measure of angst over Norway's fossil fuel derived wealth, an acceptance that wealth entails responsibility, and a preoccupation with policies that either reduce emissions associated with high consumption living or at least atone for that high consumption through generous international policies. This angst would not arise were it not for a prior conception of Norway's national identity as egalitarian and "good", and of Norway's role in the world as a "good state". ${ }^{26}$ The Norwegian state has been closely tied to forces on the centre-left for more than 100 years, and this has helped to shape a benevolent foreign policy, or "regime of

\footnotetext{
${ }^{23}$ See in particular, Prime Minister Jens Stoltenberg, Inaugural Address by the Government to the Storting, 22 March 2000. Available at: http://www.regjeringen.no/nb/dokumentarkiv/RegjeringenStoltenberg-I/smk/Taler-og-artikler-arkivertindividuelt/2000/inaugural address by the government.html?id=263704

See also, Hovden and Lindseth, "Discourses in Norwegian Climate Policy", pp. 68-70; Eivind Hovden and Gard Lindseth, "Norwegian Climate Policy 1989-2002", pp. 152-153.

${ }^{24}$ An Industry for the Future, p. 7

25 The national action discourse does not reject the use of flexibility mechanisms completely - it merely argues that their use must be contained to enable national responsibility to be sufficiently discharged rather than outsourced.

${ }^{26}$ Peter Lawler, "The Good State: In Praise of 'Classical' Internationalism”, Review of International Studies, Vol. 31 (2005), pp. 435-436.
} 
goodness". ${ }^{27}$ The self-understanding of Norway as both a "humanitarian superpower" and "environmental pioneer" is continually reproduced throughout all manner of political texts, from official policy documents to political memoirs and speeches. ${ }^{28}$ These texts display considerable pride in Norway's international benevolence, which includes support for global distributive justice, human rights, the right of self-determination, generous overseas aid and development assistance, peace, conflict resolution and Gro Harlem Brundtland's legacy of sustainable development. ${ }^{29}$ Even Norwegian scholars who take a more sceptical view of Norway's idealism concede that "ideals and interests have merged in the sense that ideals are included in a broadened notion of interests and interests are pursued through the language and practices of idealism". ${ }^{30}$

In sum, Norwegian national discourses of climate responsibility have clearly accepted leadership obligations under the UNFCCC, grounded in differentiated responsibilities, but in a special Norwegian way. Norwegian political elites construct Norway as a fine and blessed country that wishes to bless other with the same opportunities, good fortune and sense of social egalitarianism, but not in ways that undermine Norway's key source of wealth: oil. Indeed, the global arm of the Norwegian Government Pension Fund, commonly known as the Oil Fund, is based largely on taxes and license fees from the Norwegian oil industry and dividends from the majority state-owned Statoil. As the largest sovereign wealth fund in the world, the Oil Fund is designed to build up savings for future generations as the oil wealth declines, while smoothing out fluctuating oil prices along the way. Norway is aware that the day will come when it can no longer depend on oil, or gas. However, it will be prepared.

\section{Australia: From Denial to Conditional Co-operation, or Just Doing a "Fair Share"}

\footnotetext{
${ }^{27}$ On Norway's benevolent foreign policy, see Øyvind Østerud and Per Selle, "Power and Democracy in Norway: The Transformation of Norwegian Politics", Scandinavian Political Studies 29, 1 (2006), pp. 25-46 at p. 26. For a cultural history of the "regime of goodness", see Nina Witoszek, The Origin of the "Regime of Goodness": Remapping the Cultural History of Norway (Oslo, 2011). Witoszek attributes the phrase "regime of goodness" to Terje Tvedt, who formulated it in light of Gro Harlem Brundtland's claim that "It is typically Norwegian to be good" (p. 13).

${ }^{28}$ I have borrowed the terms "humanitarian superpower" and "environmental pioneer" from Kristian Stokke, "The Soft Power of a Small State: Discursive Constructions and Institutional Practices of Norway's Peace Engagement", Journal of Power, Conflict and Democracy in South and Southeast Asia, Vol. 2, 1 (2010), pp. 137-173.

${ }^{29}$ Østerud and Selle, "Power and Democracy in Norway", p. 49.

${ }^{30}$ Stokke, "The Soft Power of a Small State", p. 145.
} 
The climate discourses of Australian political leaders are much more fractured than those of their Norwegian counterparts, and this reflects a much more adversarial political culture and a much less cohesive sense of national identity.

Unlike their Norwegian counterparts, there is a much greater strain of climate denialism among the Liberal and National parties (as well as some Labor members), which is reflected in their discourses both in government and opposition. ${ }^{31}$ This has helped to produce an intensely polarised debate along the major party lines that includes division over the urgency of the problem, Australia's international responsibility vis-à-vis developing countries, the type and degree of engagement with the multilateral climate negotiations and the choice of climate policy instruments. Yet in many ways this is a faux contest in terms of underlying policy goals, since it deflects attention from the bipartisan consensus among the Coalition and the Labor party on Australia's modest unilateral mitigation target pledged at Copenhagen. Only the Australian Greens have argued that Australia's climate ambition should be radically raised to reflect scientific recommendations.

The dominant climate discourse under the Howard government (1996-2007) had echoed the Bush regime: that climate leadership was essentially a sucker's game and a threat to national economic prosperity. National mitigation effort by Australia would be cancelled out (and therefore "wasted") by rising emissions in rapidly growing developing countries, and differentiated commitments would produce an uneven international economic playing field that would give rise to "carbon leakage" (the relocation of emissions intensive industry to developing countries, with no net global reduction in emissions). Yet the Coalition's discourse also invoked the idea of differentiation in defence of a more generous Kyoto target for Australia relative to other developed countries due to Australia's special circumstances (such as a rapidly growing population, the emissions intensive nature of the economy and relatively small aggregate emissions). The over-arching narrative constructed climate leadership and economic prosperity as a zero-sum game, and sought to normalise a simple "nation-before-planet" discourse of responsibility that legitimated the continuation of a carboniferous path to national prosperity.

The Rudd Labor government's discourse marked a sharp break with its predecessor by emphasising the seriousness of climate change, and characterising it as a "great moral challenge" as well as a security threat. However, both of these frames proved to be

\footnotetext{
${ }^{31}$ Anita Talberg and Stephen Howes, "Party divides: expertise in and attitude towards climate change among Australian Members of Parliament", CCEP working paper 8.10, October 2010 (Centre for Climate Economics \& Policy, Crawford School of Economics and Government, The Australian National University).
} 
ephemeral. ${ }^{32}$ Rudd's discourse also sought to cast aside Australia's reputation as a climate laggard by accepting that developed countries have a responsibility to do more than developing countries, and embracing the idea of good international citizenship and diplomatic and national leadership. However, "leadership" did not mean bold unilateral action to set an example for others; rather, it rested on a sliding scale of ambition that depended on what others (particularly the major emitters) might do. ${ }^{33}$

At the national level, putting a price on carbon was defended as setting Australia on a path of ecological modernization, enabling it to seize the "win-win" advantages provided by technological innovation in both renewable energy and "clean coal". ${ }^{34}$ Rudd's discourse had few qualms about taking full advantage of international carbon markets in providing leastcost abatement options, and continuing investment in fossil fuel exploration, production and export.

However, the Rudd government was soon confronted with an aggressive, antileadership discourse when Tony Abbott replaced Malcolm Turnbull as Leader of the Opposition in November 2009, in protest against Turnbull's support for an emissions trading scheme. Abbott's implacable resistance to a "price on carbon" took on a particularly pugilistic form after the formation of the minority Gillard Labor government. Australians could not trust the Gillard government because it had broken its pre-election promise not to impose a carbon tax, and it was the carbon tax, rather than climate change, that emerged as the key existential threat to the Australian way of life. The discourse of economic liberalism that underpinned the case for a price on carbon was replaced with a new economic conservatism that constructed an economy-wide price on carbon as punitive and dangerous. The science of climate change was first denigrated, then questioned and downplayed as abstract and uncertain, and lacking the authority of every day, unmediated experience, and common sense. Abbott's climate discourse is rich in the vernacular and often performed in

\footnotetext{
${ }^{32}$ See, for example, Kevin Rudd, "Climate Change: The Greatest Moral Challenge of our Generation", Youtube video posted by the Australian Labor Party, 6 August 2007. http://www.youtube.com/watch?v=CqZvpRjGtGM Matt McDonald, "The Failed Securitisation of Climate Change in Australia', Australian Journal of Political Science, vol. 47, 4 (2012), pp. 579-592.

${ }^{33}$ See, for example, Australian Government, The Carbon Pollution Reduction Scheme: Green Paper, Commonwealth of Australia: Department of Climate Change, July, 2008, p. v. The Green Paper accepted that "It is likely that developed countries will be expected to collectively contribute more than any global average figure to the global emissions reduction effort" (p. 7) but also emphasised Australia's special circumstances and high adjustment costs.

${ }^{34}$ See in particular "Kevin Rudd Commits to Emissions Trading Regime", Keynote speech on foreign policy to The Global Foundation, in Melbourne, 8 March 2007. Available at: http://australianpolitics.com/2007/03/08/rudd-commit-to-emissions-trading-regime.html See also Giorel Curran, "Ecological Modernisation and Climate Change in Australia," Environmental Politics, Vol. 18, 2 (2009), pp. 201-217.
} 
situ, wearing a hard hat and florescent safety vest, alongside the workers and industries most vulnerable to a price on carbon. His discourses are also characteristically emphatic, fortified with repetition of key categories (in one paragraph, the phrase "carbon tax" is repeated no less than eight times ${ }^{35}$ ), and laced with hyperbolic predications, such as "stop the toxic tax"; "great big tax on everything"; a "giant wrecking ball" in the economy; and "a dagger aimed at the heart of manufacturing in this country"; and the critique is backed with a "blood oath" to repeal the tax. As Kevin Rudd returned in 2013 and announced an earlier than expected move to an emissions trading scheme (from 2014), Tony Abbott continued his vitriolic campaign against pricing carbon emissions, declaring the scheme as "a so-called market in the non-delivery of an invisible substance to no one". ${ }^{36}$

The Opposition's packaged its own “direct action” policy for achieving Australia's nonbinding Copenhagen pledge avoiding the complexities of market based instruments, and avoiding any cost to industry. This framing appealed for its authority to simple home truths rather than economic modelling, such as Shadow Minister for Climate Action, Environment and Heritage Greg Hunt's early childhood lessons about the virtues of carrots rather than sticks. ${ }^{37}$ Economic instruments that place a price on carbon - normally the favoured policy instrument of liberals - are presented as a "regime based on punishment". 38

The Coalition's climate discourse requires minimal knowledge brokerage and plays on the simple binaries of danger/safety, punishment/reward and complicated/simple. There is no engagement with the principles of the international climate regime. The discourses replay the arguments of the Howard years, and take it to be self-evident that no leader would support Australia moving ahead of major economies like the US. ${ }^{39}$

\footnotetext{
35 Tony Abbott, "Doorstop - Julia Gillard's Carbon Tax; New South Wales State Election”, 9 March 2011, http://www.liberal.org.au/Latest-News/2011/03/09/Tony-Abbott-Doorstop.asp

${ }^{36}$ Judith Ireland, "Emissions Scheme a Trade in the Invisible: Abbott", The Sydney Morning Herald, 15 July 2013. Available at: http://www.smh.com.au/federal-politics/federal-election-2013/emissions-scheme-a-trade-inthe-invisible-abbott-20130715-2pzdo.html

${ }^{37}$ Greg Hunt, "Carrots not Sticks: Rethinking Global Approaches to Climate Change (Lessons from my Mothers' Garden)”, Speech to the Lowy Institute, Monday 11 July 2011, in Greg Hunt MP, Federal Member for Flinders and Shadow Minister for Climate Action, Environment and Heritage, Australia 2030 Speeches, Published by Greg Hunt, 184 Salmon Street, Hastings, Victoria, 3915.

${ }^{38}$ Ibid.

${ }^{39}$ See Greg Hunt, "Will Gillard Have the Guts to ask Obama the Question?" The Australian, 16 November 2011. Available at http://www.theaustralian.com.au/national-affairs/opinion/will-gillard-have-guts-to-askobama-the-question/story-e6frgd0x-1226196061329; See also Greg Hunt, "Labor in Denial on Cost of Carbon Tax on Electricity", At http://www.liberal.org.au/Latest-News/2011/11/15/Labor-in-Denial-on-Cost-of-CarbonTax-on-Electricity.aspx See also "Gillard must seek Carbon Tax Clarification from Obama", at http://www.liberal.org.au/Latest-News/2011/11/15/Gillard-Must-Seek-Carbon-Tax-Clarification-FromObama.aspx
} 
The Coalition's hyperbolic resistance to a price on carbon produced a defensive and reassuring climate discourse on the part of the minority government of both Gillard and Rudd. Working families need not worry. Only "big carbon polluters" are directly subjected to the impost, while trade-exposed industries and low-income households are protected. Unlike her predecessor, Prime Minister Gillard's discourse was more focused on what the Clean Energy Future package could do for Australia rather than what Australia could do for the world as a middle power. The package was defended not as an example of leadership but rather in terms of Australia just doing its "fair share". The emphasis was therefore more on "common" rather "differentiated" responsibilities, highlighting the fact that Australia was not "going it alone" but rather moving in line with many other countries. As Prime Minister Gillard put it when announcing the interim fixed price on carbon in January 2012, "I do not believe Australia needs to lead the world on climate change, but I also do not think we can afford to be left behind". ${ }^{40}$

The Gillard's government's discourse also defended its package as a nation-building, modernising reform in the long tradition of modernisation reforms led by Labor. The Clean Energy Package would make Australia Cleaner, Smarter and Richer. ${ }^{41}$ Whereas the Coalition's key category is "carbon tax", and its discourse plays off the binaries of danger/safety, punishment/reward and complicated/simple, the Labor government's key category is "carbon pollution", and the legitimation of the government's policy package is built around the binaries of clean/dirty, modern/outdated and expert/nonexpert. In lieu of the folksy wisdom of the Opposition, the defence of the Clean Energy Future package by Gillard, and particularly her climate minister Greg Combet, drew heavily on the authority of climate science, economics and policy professionalism, including the detailed research of the Garnaut Climate Change Review. Although the Garnaut Review had defended the egalitarian principle of "equal per capita rights to use the atmosphere's limited capacity to absorb more greenhouse gases", this has been quietly passed over by Labor. ${ }^{42}$ Most references to "fairness" or "equity" in Labor's discourse are focussed on national redistributive justice rather than international redistributive justice.

\footnotetext{
${ }^{40}$ Ben Packham and James Massola, “Australia to have Carbon Price from July 1, 2012, Julia Gillard Announces”, The Australian, 23 January 2012. Available at http://www.theaustralian.com.au/news/gillard-toreveal-climate-policy-today/story-e6frg6n6-1226011223441

41 Greg Combet, Minister for Climate Change, "Climate Change: A Critical Juncture", Labor Blog, 12 September 2012. Available at: http://www.alp.org.au/blogs/alp-blog/september-2012/climate-change--a-critical/ (accessed 2 Oct. 2012); Prime Minister of Australia, The Hon Julia Gillard, "Address to the Carbon Expo Australasia 2011, Melbourne”, 8 Nov 2011. Available at: http://www.pm.gov.au/press-office/address-carbon-expo-australasia-2011-melbourne

${ }^{42}$ See Garnaut Review (xiv-xv, and Chapter 9)
} 
The fractured national climate discourses rest on significant differences between the Coalition, Labor and the Greens over Australia's role in the world (aside from the strong bipartisan support over the centrality of the US alliance, and a shared conception of Australia as a "middle power"). The Coalition's foreign policy tradition has tended to be reactive, pragmatic, realist and prone to practice a more selective á la carte multilateralism or engage in voluntary international partnerships in ways that are more closely wedded to the US Alliance. Australia's role in the world is to protect its national interests, which includes enjoying the benefits of a resource rich economy and upholding the (energy-intensive, high consumption) 'Australian way of life'. This is a highly defensive posture towards the world, and one in which the role of activist leadership, based on cosmopolitan principles, makes no sense.

In contrast, the Labor Party has tended to be more committed to the United Nations and multilateralism, and to defend the virtues of Australia's role as a "good international citizen", ${ }^{43}$ or an "enlarger" rather than "straightener", to borrow Gareth Evans' reframing of the role conception he created for Labor. ${ }^{44}$ However, while Evan's particular articulation of this role sees Australia working cooperatively towards the protection of global public goods, this was only one of three prongs in his foreign policy framework. Good citizenship would necessarily have to be tempered by the other two prongs, namely, the protection of Australia's geopolitical/strategic and economic interests. Labor's climate discourse of conditional cooperation, of doing a fair share and no more, is in clear alignment with this particular foreign policy tradition, which leaves plenty of room for caveats and contradictions.

The Garnaut Review had also defended the idea of Australia playing "its full proportionate part in global action" and that "[a]s one of the developed countries, its full part will be relatively large, and involve major early changes to established economic structure". ${ }^{45}$ However, as we have seen, Labor has preferred to run with the more shrunken notion of a "fair share", which means accepting a form of conditional responsibility that keeps a close eye on what others are doing, rather than engaging in exemplary unilateral action designed to set an example for others to follow. A good international citizen, after all, is just a good

\footnotetext{
${ }^{43}$ Gareth J. Evans and Bruce Grant, Australia's Foreign Relations: In the World in the 1990s, $2^{\text {nd }}$ ed. (Melbourne, 1995), 33-5.

${ }^{44}$ Gareth Evans, "Enlargers, Straiteners and the Making of Australian Foreign Policy", 12th Annual Manning Clark Lecture, Canberra, 3 March 2011 (subsequently published in edited form in Meanjin Quarterly, Vol. 70, 2 (2011), p. 130.

${ }^{45}$ Garnaut Review 2008, xvii and Chapter 9.
} 
member rather than good leader of international society, even if it plays a worthy and sometimes activist role.

Unlike Norwegian national climate discourses, Australian climate discourses (aside from the Greens) remain untroubled by the contradictions with national energy policy. Indeed, there is strong bipartisan support for Australia's rising coal and gas exports, with the prospects of "clean coal" and stricter regulation resolving any tensions with climate policy. The government has also been able to hide behind the greenhouse gas accounting rules of the climate regime, which only measure emissions produced within the territory rather those associated with exports and imports. These accounting rules, along with the Kyoto flexibility instruments and "Australia clause", have enabled Australia's performance on mitigation to remain more or less within the technical letter of the Kyoto Protocol rather than the substantive spirit of the larger international climate regime. ${ }^{46}$

Finally, the discursive struggle over climate policy in Australia cannot be divorced from the struggle over resource rents and mining taxes. The Rudd Labor government's proposed Resource Super Profit Tax on Australia's mining industry (amounting to a $40 \%$ tax on "super profits") had generated a major media war between the government and the powerful mining industry, supported by the federal opposition. The Gillard Labor government subsequently introduced a watered down Mineral Resource Rent Tax on profits from non-renewable resources, which was finally enacted in November 2011 with the support of the Greens and two Independents. ${ }^{47}$ Unlike Norway, Australia does not have a sovereign wealth fund built up from the wealth it has derived from its large resources sector. ${ }^{48}$ When the rest of the world moves away from fossil fuel, Australia will be unprepared.

\section{Conclusion}

It is clear from the foregoing analysis that political leaders have considerable creative power in narrating national responsibility for climate change, and what part, if any, fossil fuels should play in this narrative. This creative power is both constrained and enabled by the

\footnotetext{
${ }^{46}$ The so-called so-called "Australia clause" in the Kyoto Protocol, negotiated by the Howard government, allows changes in emission from land-clearing to be included in calculation of emissions trajectories, which effectively inflates Australia's 1990 baseline.

${ }^{47}$ This initiative set a lower tax of $30 \%$ on assessable profits of the non-renewable resources sector (including coal).

${ }^{48}$ The Howard government had established a Future Fund in 2006, but the purpose of this fund was to cover the government's accumulated unfunded liability for public service and defence force pensions.
} 
relative bandwidth of agreement and disagreement about national identities and international role conceptions in each country. Norway's climate policy discourses are profoundly shaped by a widely shared conception of Norway as a "benevolent state" dispensing a "regime of goodness" in foreign policy and diplomacy. Australia's climate policy discourses reveal a much more fractured national identity and associated conceptions about Australia's proper role in the world as a middle power, which ranges from loyal US ally and defensive realist to a good international citizen (as distinct from leader).

These differences are crucial to understanding why, despite a common commitment to social justice, the Norwegian Labour government has been much more responsive to the UNFCCC's call for climate leadership than the Australian Labor government, and why it has been more troubled by the contradiction between its climate and energy policies. However, the management of this contradiction - through international generosity, the use of international carbon markets and a national discourse of technological heroism and ecological modernisation - has proved problematic. Delays in the development of Statoil's Mongstad gas-fired plant have meant that Stoltenberg has yet to achieve his moon landing, and there is disquiet in and beyond the Storting over whether the relatively modest measures in the 2012 White Paper will realise Norway's leadership ambition. The legitimation challenge facing the Stoltenberg government is therefore expected to grow over time as the relationship between Norway's role as a "climate leader" and a "high-tech petroleum and gas producer" becomes increasingly strained. The only way to avoid this strain is to rewrite one or both of the roles.

The International Energy Agency has provided the outlines of a new script in its warning that if the world is to prevent dangerous climate change then no more than one third of proven reserves of fossil fuels can be exploited. ${ }^{49}$ This beckons a new type of integrated climate and energy leadership narrative based on not only technological ingenuity but also forbearance and thrift, enacted through a gradual phase out of fossil fuel production, combined with a major rechannelling of research and development into renewable energies, increased efficiency and reduced consumption. Norway has a stronger cultural and social democratic heritage than Australia from which to ground such an integrated narrative, drawing on national traits of hardiness, pioneership, ecological frugality, and responsibility to others - staked out by such figures as Armundsen, Nansen, Naess and Brundtland.

\footnotetext{
${ }^{49}$ International Energy Agency, World Energy Outlook 2012: Executive Summary (Paris, 2012)
} 
In contrast, Australia needs to rewrite both its national climate and energy scripts if it wishes to live up to its putative reputation of a good international citizen or creative middle power. Given the extreme modesty of Australia's 2020 unconditional emissions reduction target, it will become increasingly difficult for any Australian government to claim that it is doing a fair share, let alone acting as a leader. And given the prohibitive costs of CCS and growing interest in trade adjusted methods of carbon accounting, it will become increasingly difficult for political leaders simply to ignore the contradictions between national climate and energy policies. The irony is that Australia has much greater, untapped renewable energy resources than Norway. Moreover, the greater bandwidth of political disagreement over national identity and international role conception in Australia also creates a larger field of creative possibilities for new political leaders seeking to articulate an ecologically responsible vision of prosperity, and a new understanding of Australia's place in the world. For example, as a sun-drenched country, Australia has the makings of a benevolent nation-building narrative - a solar-power nation (and on a far bigger scale that the Snowy Mountain Hydro Scheme). Such a vision splendid, if combined with a more generous disposition towards the vulnerable at home and abroad, would give more substance and prominence to Australia's claim to be a good international citizen and put paid to the long history of thinking that the national interest requires us to prosper at the expense of others. 


\section{University Library}

\section{- M M I N E R VA A gateway to Melbourne's research publications}

Minerva Access is the Institutional Repository of The University of Melbourne

Author/s:

Eckersley, R

Title:

Poles apart?: The social construction of responsibility for climate change in Australia and Norway

Date:

2013-01-01

Citation:

Eckersley, R. (2013). Poles apart?: The social construction of responsibility for climate change in Australia and Norway. Australian Journal of Politics and History, 59 (3), pp.382-396. https://doi.org/10.1111/ajph.12022.

Persistent Link:

http://hdl.handle.net/11343/260525 